\title{
限流ヒューズ用動作シミュレーション 手法の開発と実証
}

\author{
正員 岡 崎 正 幸 (電中研) \\ 正員稲 葉 次紀 (電中研)
}

\section{1. まえがき}

限流ヒニーズは，その原理上遮断時に動作過電圧を 発生する。この動作過電壬が他の機器にどのような影 響を与えるか十分検討するととが必要である。

限流七ューズの動作過電圧は使用するヒューズ形 式，事故形態ならびに回路条件などにより異なる。し かし，これらの組合せをすべて実規模試験で検討する ことは困䧼なため，コンピュータにより動作状況をシ ミュレートすることができれば，遮断現象の解明を効 果的に僬めることが可能となる。

そこで，ノッチ付ヒニーズエレメントを用いた限流 ヒニーズの発挀後のアーク電压をアークエネルギーと 時間の関数で表した，電压成分と抵抗成分を用いて解 析するシミュレーション手法(1)登開し， $20 \mathrm{kV}$ 級限 流ヒューズを用いた遮断実験により，その有効性を確 認した。

\section{2. シミュレーション手法}

〈2.1〉基本的考え方 四10回路において,スイ ッチ $S_{m}, S_{i}$ を閉路しておき, 通電開始スイッチ $S w$ を閉路すれば，供試ヒ二ーズに $I_{f}$ が流れる。電流 $I_{f}$ のジニール積分が供試ヒューズの溶断ジュール皘分を 超えれば，ヒューズエレメントは溶断する。この溶断 をスイッチ $S_{m}$ を開路することにより模擬する。それ 以降, アーク電圧の電压成分 $V_{a r}$ 亡抵抗成分 $R_{a}$ で 表される特性要素が回路に插入され，ヒューズの端子 電压 $V_{f}$ と電流 $I_{j}$ を回路方程式江適用し，逐次計算 を行う。䉓流 $I_{f}$ が減少し，零になった時点でとュー

Development of a Operating Simulation Method for Current Limiting Fuses and its Actual Proof. By Masayuki Okazaki, Member \& Tsuginori Inaba, Member (Yokosuka Research Laboratory, Central Research Institute of Electric Power Industry).

岡崎正幸：正員，電力中央研究所 横㮌賀研究所

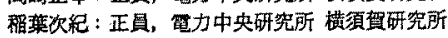

ズが遮断完了したと判断し，スイッチ $S_{i}$ を開路す る。それ以降は再起電圧調整用キャパシタ $C_{p}$ のイン ピーダンス $Z_{i p}$ が電源リアクトルのインピーダンス $Z_{L S}$ より大稫に大きいため, ヒューズ端子には電源 電在 $V$ sがそのまま印加される。

〈2・2〉 ヒューズエレメントの形状と溶断過程

検討に用いたヒューズエレメント形状を図 2 に, 寸 法を表1に示す。同図に示すノッチ付ヒューズェレメ ントのノッチ部上平たん部（ノッチのない部分）の溶 断ジニール積分は舆なる。このため，ヒニーズエレメ

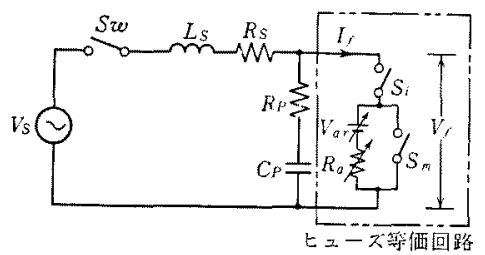

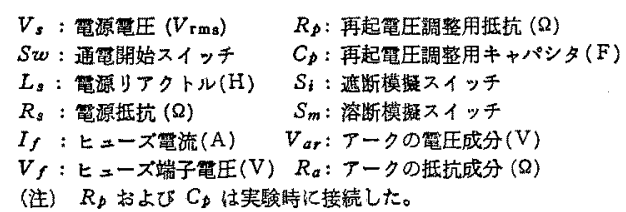

図 1 基本回路

Fig. 1. Basic circuit of simulation.
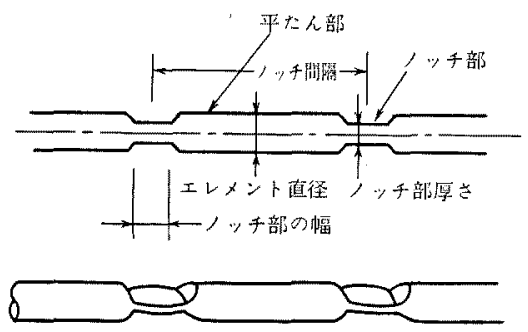

図 2 ヒューズエレメント形状

Fig. 2. Form of a fusible element. 
表 1 ヒューズエレメント寸法

Table 1. Dimensions of fusible elements.

\begin{tabular}{|c|c|c|c|c|c|c|c|}
\hline 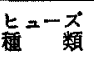 & $\underset{(\mathrm{mm})}{ \pm}$ & $\begin{array}{c}\text { 我部要き } \\
(\mathrm{mm})\end{array}$ & $\begin{array}{c}\text { ノッ部の㜔 } \\
(\mathrm{mm})\end{array}$ & $\begin{array}{l}\text { y千㖰膘 } \\
(\mathrm{mm})\end{array}$ & ノッチ部個数 & $\begin{array}{c}\text { エレメント全是 } \\
(\mathrm{mm})\end{array}$ & 圠ント \\
\hline$A$ & 0.16 & 0.11 & 0.5 & 3.18 & 約 790 & 2,500 & 1 \\
\hline$B$ & 0.23 & 0.11 & 0.5 & 3.18 & 630 & 2,000 & 3 \\
\hline$C$ & 0.23 & 0.11 & 0.5 & 3. 18 & 630 & 2,000 & 3 \\
\hline$D$ & 0.37 & 0.08 & 0.5 & 3. 18 & 590 & 1,870 & 8 \\
\hline$E$ & 0.45 & 0.08 & 0.5 & 3.18 & 420 & 1,330 & 8 \\
\hline$F$ & 0.55 & 0.08 & 0.5 & 3. 18 & 510 & 1,617 & 4 \\
\hline$G$ & 0.55 & 0.16 & 0.5 & 3.18 & 390 & 1,040 & 4 \\
\hline
\end{tabular}

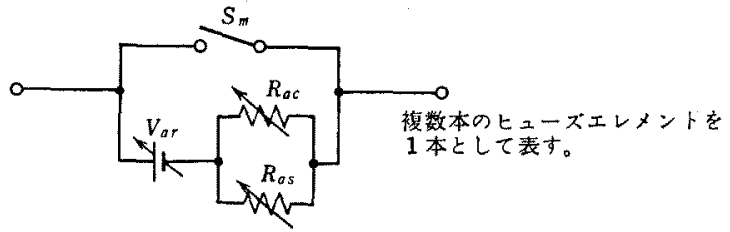

$\downarrow$

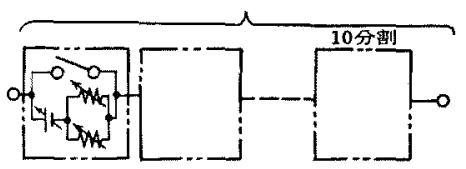

$\Downarrow$

10分割する。

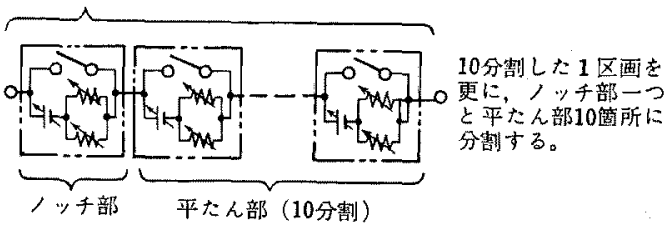

図 3 ヒューズモデルの分割状況

Fig. 3. Divided condition of fuse model.

ントに電流を流甘ば，ジュール熱により，初めにノッ チ部が，次いで平たん部が溶断する。しかしノッチ部 が溶断発弧すれば，その両側の平たん部はアークの電 極となるため，平たん部は自分自身のジュール熱に加 えてアークにより直接加熱され溶融・発弧する(2)(3)。

〈2.3〉ヒューズエレメントの分割 ノッチ部枋 よび平たん部における溶断ジュール積分值のばらつき および平たん部のアークによる溶融を考慮するため七 ニーズエレメントを多数の区画化分割し（図 3 参照）, その最小単位ごとに溶断時間さよびアーク電壬を計算 した。

供試したヒニーズエレメントのノッチ部の実際の数 は 300 以上 (表 1 参照)である。また平たん部のアー クによる溶融は連続的なため，正確に模擬するのに必 要な分割数は無限大となる。ノッチ部数および平たん 部分割数を多くすることは実際汇近くなり，詳細なシ
ミュレーションが可能となるが，他方，計算時間の增 大となる。とのため, 試計算(1)からヒニーズリンク 1 本のヒューズエレメント本数を並列数によらず1本と し，そのヒューズエレメントのノッチ部书よび平たん 部をそれぞれ 10 箅所とし，平たん部は更に各々を 10 分割した。この最小単位(ノッチ部 10，平たん部 100) はそれぞれスイッチ $S_{m}$ ，電王成分 $V_{a r}$ ，抵抗成分 $R_{a}$ (抵抗成分 $R_{a}$ をアーク 周辺部の抵抗成分 $R_{a s}, ア ー$ $\eta$ 中心部の抵抗成分 $R_{a c}$ の二つに分解した。〈2.5〉節 2 項参照〉で構成し，スイッチ $S_{m}$ を開いてからの時 間ならびに，その部分のアークエネルギにより各値を 計算する。

〈2・4〉溶断シュール皘分 溶断ジーール皘分は溶 断時間が短い場合には，ほ浪一定值であると報告(む)(5) されているが，ててでは詳細に模擬するため，ノッチ 部で発生した熱が主に平たん部および消弧砂に放熱す 
ると考え, 溶断時間 $t(\mathrm{~s})$ が, $t=0 \sim 5 \mathrm{~ms}$ の範囲にお いて次式で表されるすのとした。

$$
\left(I^{2} t\right)_{m}=\left(I^{2} t\right)_{m_{0}} \times\left(1+K_{m_{1}} \times t^{k_{m}}\right) \ldots \ldots(1)
$$

ここに, $\left(I^{2} t\right)_{m}:$ 溶断ジュール皘分 $\left(A^{2} s\right)$,

$\left(I^{2} t\right)_{m_{0}}$ : 基準となる溶断ジュール皘分 $\left(A^{2} s\right)$,

$K_{m_{1}}$ : 溶断ジュール積分の俰数, $K_{m_{3}}$ : 溶断

ジュール積分の指数

またノッチ部および平たん部とも，分割した最小単 位の基準となる溶断ジュール積分 $\left(I^{2} t\right)_{m o}$ は，製作上 の裕度を考慮するため同一值とせず，士10\%のばらつ き幅で正規分布を模擬した。

$\langle 2.5\rangle$ アーク電圧 ヒューズエレメント溶断後 のアーク電圧（ヒニーズの端子電压 $V_{S}$ ) は, 基本的 に次式で表した。

$$
V_{f}=V_{a r}+I_{f} \cdot R_{a}
$$

ここに, $V_{a r}:$ アーク電圧の電圧成分 $(\mathrm{V})$,

$R_{a}:$ アーク電压の抵抗成分 $(\Omega)$

アーク電圧を電圧成分と抵抗成分（抵抗降下電王） の直列回路で構成する試みに関しては既に報告(1)-(4) がある。本諭文も基本的には同様であるが，アークエ ネルギーと時間と関数として表すととを試みた。

(1) アークの電圧成分 ヒューズ筒内のアーク の物理的状況は, 不明热点加多いすのの次のように概 念的化推定する。ヒューズエレメント溶断直後のアー クの状況は自由空間に扔りる通常のアークと異なり，

充てんしてある消弧砂のすきまにアークが発生する。 このため，アークの断面積は小さく単位長あたりの電 圧（電界）はかなり高いと考えられる。時間が経過 し、アークにより消弧砂の溶融・気化か進めは，すき まが広がり，アークの断面皘古大きくなりアークの電 界は低下すると考えられる。また，アークエネルギー により温度が上昇すれぱ，アークの導電率が上昇し， アークの電界は低下する。更に，消弧砂の気化侸よる 王力上㫒によってアークの電界は上昇する。

このように，アークの電界は複䧴な要因により变化 するが，ここではアークエネルギーにより減少すると して、アークの電圧成分 $V_{a r}$ は次式往うあのとした。

$$
\begin{aligned}
V_{a r_{(n)}}= & V_{a r a} \times\left[\exp \left\{-W_{a}(n) / \omega_{a r}\right\}\right. \\
& \left.+\exp \left\{-W_{a}(n) /\left(0.1 \times \omega_{a r}\right)\right\}\right]
\end{aligned}
$$

ここに, $V_{a r(n)}: n$ 番目の最小単位における アークの電圧成分 $(\mathrm{V}), V_{a r o}$ : アークの電圧 成分一定值 $(\mathrm{V}), W_{a(n)}: n$ 番目の最小単位

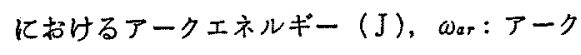
の電圧成分減少指数 (J)
上式の第 2 項は消弧砂儿含まれる砂のうち，特に直徍 の小さい砂を考慮したすのである。溶融気化する消弧 砂の体積がアークエネルギーに比例するすのとすれ ば, 直隹の小さい消弧砂ほど早く消滅する。直径が約 1/2(体皘 1/10) の消弧砂が湿入していると考え, $\omega_{a r}$ を標準的な砂の場合の $1 / 10$ とした。この項は $W a の$ 小さいときのみ $V_{a r}$ に関与する。

またノッチ部のみ溶断し，平たん部が未溶断の間 は，電極降下電圧 $V_{L}$ (正極十負極）をノッチ部の電 王成分に加算した。

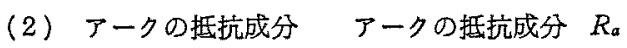
も最小単位についてそれぞれ計算する。アークの断面 を考えるとアークの中心部と周辺部では, その温度， 消弧砂とのかかわりも異なるため，ここでは周辺部の 抵抗成分と中心部の抵抗成分を区分し，それらを並列 させて全体の抵抗とした。

アークと消弧砂との関係を次のように推定する。七 ニーズエレメントが溶断し発生したアークは, 時間の 経過従いアーク半径が大きくなる。アークの周辺部 ではアーク半径が大きくなるに従い, アークの周辺長 が増大するため, 溶融・冷却に費やすエネルギーが周 辺長に比例するあのとすれば，見散け上，アーク周包 部の抵抗成分は時間と共譜大する。

またアークの中心部では，アークにより消弧砂の表 面が溶融し直径が減少する。このため, アークを泠却 する表面積が減少しアーク抵抗は低下する。

(i) アーク周过部の抵抗成分 $R_{a s(n)}$ は次式に従 うとした。

$R_{a s_{(n)}}=K_{R_{a s}} \times t_{a_{(n)}}$

ここに, $R_{a s(n)}: n$ 番目の最小単位における アーク周辺の抵抗成分 $(\Omega), K_{R_{a s}}:$ アーク周 辺部の抵抗成分增加速度 $(\Omega / \mathrm{s}), t_{a(n)}: n$ 番目 の最小単位の溶断後の時間 ( $\mathrm{s}$ )

（ii）また，アーク中心部の抵抗成分 $R_{a c(n)}$ は，次 式に従うとした。

$$
\begin{aligned}
R_{a c_{(n)}}= & R_{a c o} \times\left[\exp \left\{-W_{a_{(n)}} / \omega_{a c}\right\}\right. \\
& \left.+\exp \left\{-W_{a_{(n)}} /\left(0.1 \times \omega_{a c}\right)\right\}\right]
\end{aligned}
$$

ここに, $R_{a c(n)}: n$ 番目の最小単位における アーク中心部の抵抗成分 $(\Omega), R_{a c o}:$ アーク 中心部の抵抗成分一定值 $(\Omega), \omega_{a c}: ア ー ク$ 中 心部の抵抗成分減少指数 $(\mathrm{J})$

(5)式の第 2 項はアークの電圧成分と同様に, 直径 の小さい消弧砂の影響を加味したものである。

(3) ノッチ部のアークによる平たん部の溶融 ノッチ部が溶断発弧したのち, そのノッチ部に臨接 
表 2 シミニレーション動作定数

Table 2. Constant values for simulation.

\begin{tabular}{|c|c|c|c|c|c|c|c|c|c|c|c|}
\hline \multirow{3}{*}{ 程 } & \multirow{3}{*}{ 個 所 } & \multicolumn{3}{|c|}{ 溶断シニール䅦分 } & \multirow{2}{*}{$\begin{array}{l}\text { 平たん部 } \\
\text { 溶蠤保数 }\end{array}$} & \multirow{2}{*}{ 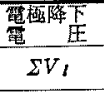 } & \multicolumn{2}{|c|}{ アーク耎王成分 } & \multirow{2}{*}{ 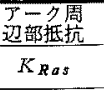 } & \multicolumn{2}{|c|}{ アーク中心部抵抗 } \\
\hline & & $\left(I^{2} t\right) m_{0}$ & $K_{m 1}$ & $K_{m 2}$ & & & $V_{a r o}$ & $\omega_{a r}$ & & $R_{a c 0}$ & $\omega_{a t}$ \\
\hline & & $A_{s}{ }^{2}$ & - & - & $\mathrm{A} \cdot \mathrm{s} /$ 個 & $\mathrm{v}$ & v & $\mathrm{J}$ & $\Omega / \mathrm{s}$ & $\Omega$ & $\mathrm{J}$ \\
\hline$A$ & $\begin{array}{l}\text { ノッチ部 } \\
\text { 平たん部 }\end{array}$ & $\begin{array}{l}17 \\
70 \\
\end{array}$ & $\begin{array}{l}5.4 \\
0 \\
\end{array}$ & $\begin{array}{l}0.32 \\
0\end{array}$ & 1.0 & $12 \times 10^{3}$ & $\begin{array}{c}350 \\
28.2 \times 10^{3}\end{array}$ & $\begin{array}{l}2.6 \times 10^{4} \\
2.6 \times 10^{4} \\
\end{array}$ & $\begin{array}{r}12 \times 10^{3} \\
960 \times 10^{3} \\
\end{array}$ & $\begin{array}{r}5.2 \\
416\end{array}$ & $\begin{array}{l}2.4 \times 10^{4} \\
2.4 \times 10^{4}\end{array}$ \\
\hline$B$ & $\begin{array}{l}\text { イッチ部 } \\
\text { 平たん部 }\end{array}$ & $\begin{array}{l}400 \\
680\end{array}$ & $\begin{array}{l}21 \\
34\end{array}$ & $\begin{array}{l}0.55 \\
0.9\end{array}$ & 0.4 & $10 \times 10^{3}$ & $\begin{array}{r}2.9 \times 10^{3} \\
14.7 \times 10^{3}\end{array}$ & $\begin{array}{l}9 \times 10^{4} \\
9 \times 10^{4} \\
\end{array}$ & $\begin{array}{r}80 \times 10^{3} \\
400 \times 10^{3} \\
\end{array}$ & $\begin{array}{l}10 \\
50 \\
\end{array}$ & $\begin{array}{l}1.1 \times 10^{5} \\
1.1 \times 10^{5} \\
\end{array}$ \\
\hline$C$ & $\begin{array}{l}\text { ノッチ部 } \\
\text { 平た九部 }\end{array}$ & $\begin{array}{l}500 \\
800\end{array}$ & $\begin{array}{l}4.8 \\
0\end{array}$ & $\begin{array}{l}0.48 \\
0\end{array}$ & 0.4 & $10 \times 10^{3}$ & $\begin{array}{r}2.2 \times 10^{3} \\
11.0 \times 10^{3} \\
\end{array}$ & $\begin{array}{l}2.5 \times 10^{5} \\
2.5 \times 10^{5} \\
\end{array}$ & $\begin{array}{r}30 \times 10^{3} \\
150 \times 10^{3}\end{array}$ & $\begin{array}{l}11.5 \\
57.5\end{array}$ & $\begin{array}{l}8.8 \times 10^{4} \\
8.8 \times 10^{4}\end{array}$ \\
\hline$D$ & $\begin{array}{l}\text { ノッチ部 } \\
\text { 平たん部 }\end{array}$ & $\begin{array}{l}14 \times 10^{3} \\
43 \times 10^{3}\end{array}$ & $\begin{array}{c}8.6 \times 10^{-6} \\
0\end{array}$ & $\begin{array}{l}3.24 \\
0 \\
\end{array}$ & 2.0 & $9 \times 10^{3}$ & $\begin{array}{r}2.7 \times 10^{3} \\
13.2 \times 10^{3} \\
\end{array}$ & $\begin{array}{l}\text { 1. } 8 \times 10^{6} \\
\text { 1. } 8 \times 10^{6} \\
\end{array}$ & $\begin{array}{r}28 \times 10^{3} \\
140 \times 10^{3}\end{array}$ & $\begin{array}{r}3 \\
15\end{array}$ & $\begin{array}{l}7 \times 10^{5} \\
7 \times 10^{5} \\
\end{array}$ \\
\hline$E$ & $\begin{array}{l}\text { ノッチ部 } \\
\text { 平た九部 }\end{array}$ & $\begin{array}{l}20 \times 10^{3} \\
94 \times 10^{3}\end{array}$ & $\begin{array}{c}2.1 \times 10^{5} \\
0\end{array}$ & $\begin{array}{l}2.52 \\
0\end{array}$ & 2.0 & $7 \times 10^{3}$ & $\begin{array}{l}1.6 \times 10^{3} \\
8.1 \times 10^{3}\end{array}$ & $\begin{array}{l}1.8 \times 10^{6} \\
1.8 \times 10^{6}\end{array}$ & $\begin{array}{r}7 \times 10^{3} \\
35 \times 10^{3} \\
\end{array}$ & $\begin{array}{c}2.4 \\
12 \\
\end{array}$ & $\begin{array}{l}5.6 \times 10^{5} \\
5.6 \times 10^{5} \\
\end{array}$ \\
\hline$F$ & $\begin{array}{l}\text { ノッチ部 } \\
\text { 平た九部 }\end{array}$ & $\begin{array}{r}5.5 \times 10^{3} \\
53 \times 10^{3} \\
\end{array}$ & $\begin{array}{c}6.5 \times 10^{5} \\
0\end{array}$ & $\begin{array}{l}2.55 \\
0 \\
\end{array}$ & 1.5 & $8 \times 10^{3}$ & $\begin{array}{l}2 \times 10^{3} \\
9 \times 10^{3} \\
\end{array}$ & $\begin{array}{l}1.4 \times 10^{6} \\
1.4 \times 10^{6}\end{array}$ & $\begin{array}{r}21 \times 10^{3} \\
105 \times 10^{3}\end{array}$ & $\begin{array}{r}7 \\
35 \\
\end{array}$ & $\begin{array}{l}5.4 \times 10^{3} \\
5.4 \times 10^{5} \\
\end{array}$ \\
\hline$G$ & $\begin{array}{l}\text { ノッチ部 } \\
\text { 平たん部 }\end{array}$ & $\begin{array}{l}26 \times 10^{3} \\
53 \times 10^{2}\end{array}$ & $\begin{array}{c}3.1 \times 104 \\
0\end{array}$ & $\begin{array}{l}2.6 \\
0\end{array}$ & 1. 0 & $5 \times 10^{3}$ & $\begin{array}{l}1.6 \times 10^{3} \\
7.8 \times 10^{3}\end{array}$ & $\begin{array}{l}1.8 \times 10^{6} \\
1.8 \times 10^{6}\end{array}$ & $\begin{array}{r}9 \times 10^{3} \\
45 \times 10^{3}\end{array}$ & $\begin{array}{c}2.2 \\
11\end{array}$ & $\begin{array}{l}4.2 \times 10^{5} \\
4.2 \times 10^{5}\end{array}$ \\
\hline
\end{tabular}

（注）各定数は、最小箸位一つ分の徝でなくヒューズは本分の值である。

表 3 実試駼值とシミュレーションの比較

Table 3. Comparison of test results and simulation values.

\begin{tabular}{|c|c|c|c|c|c|c|c|c|c|c|c|c|c|c|c|c|}
\hline \multirow{3}{*}{$\begin{array}{l}\text { ヒa } \\
\text { - } \\
\text { 程類 }\end{array}$} & \multirow{3}{*}{ 福別 } & \multicolumn{3}{|c|}{ 回路条件 } & \multicolumn{3}{|c|}{ 限 流 值 } & \multicolumn{3}{|c|}{ 趿作過電珐 } & \multicolumn{3}{|c|}{ アークエネルギー } & \multicolumn{3}{|c|}{ 動 作 時 閔 } \\
\hline & & $\begin{array}{l}\text { 電源 } \\
\text { 電秕 }\end{array}$ & $\begin{array}{l}\text { 固 有 } \\
\text { 電 流 }\end{array}$ & $\begin{array}{l}\text { 投 } \\
\text { 位相角 }\end{array}$ & 実試䮦 & 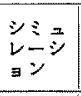 & 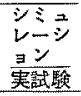 & 実試䮦 & $\begin{array}{l}シ ミ 2 \\
レ ニ シ 2 \\
\exists ン\end{array}$ & 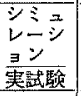 & 実試駿 & 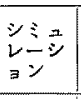 & 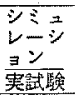 & 克試轲 & $\begin{array}{l}シ ミ ュ ~ \\
\text { レシジ } \\
\exists ン\end{array}$ & 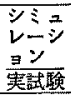 \\
\hline & & $\mathrm{kV}$ & $\mathrm{kA}$ & deg & $\mathrm{kA}$ & $\mathrm{kA}$ & - & $\mathrm{kV}$ & $\mathrm{kV}$ & - & $\mathrm{kJ}$ & $\mathrm{kJ}$ & - & $\mathrm{ms}$ & ms & - \\
\hline \multirow{2}{*}{$A$} & 小電流 & 20.9 & 0.55 & 46 & 0.32 & 0.31 & 0.97 & 65.6 & 67.4 & 1.03 & 17.8 & 16.9 & 0.95 & 6.05 & 6.02 & 1.00 \\
\hline & 大電潜 & 20.9 & 16 & 67 & 0.81 & 0.95 & 1. 17 & 62.5 & 66.1 & 1.06 & 5.1 & 4.2 & 0.82 & 3.15 & 0.34 & 0.11 \\
\hline \multirow{2}{*}{$B$} & 小䨌㴶 & 20.9 & 0.94 & 13 & 0.92 & 0.90 & 0.98 & 65.4 & 63.4 & 0.97 & 89.1 & 88.6 & 0.99 & 9.80 & 9.69 & 0.99 \\
\hline & 大電流 & 20.9 & 16 & 72 & 2. 12 & 2.08 & 0.98 & 70.7 & 71.8 & 1.02 & 36.6 & 36.3 & 0.99 & 4. 25 & 4. 32 & 1.02 \\
\hline \multirow{2}{*}{$C$} & 小電流 & 20.9 & 0.94 & 12 & 0.91 & 0.90 & 0.99 & 54.0 & 52.4 & 0.97 & 95.9 & 95.0 & 0.99 & 9.97 & 9.65 & 0.97 \\
\hline & 大雹流 & 20.9 & 16 & 65 & 2.19 & 2.18 & 0.99 & 62.0 & 58.0 & 0.94 & 59.5 & 58.6 & 0.98 & 5.16 & 4.97 & 0.96 \\
\hline \multirow{2}{*}{$D$} & 小電流 & 31.3 & 2 & 33 & 3. 65 & 3.49 & 0.96 & 76.3 & 76.8 & 1.01 & 500 & 496 & 099 & 10.3 & 9.93 & 0.96 \\
\hline & 大電流 & 31.3 & 10 & 52 & 5.96 & 5.75 & 0.96 & 91.2 & 91.1 & 1.00 & 606 & 579 & 0.96 & 6.71 & 6.76 & 1.00 \\
\hline \multirow{2}{*}{$E$} & 小電流 & 20.9 & 2 & 5 & 4.25 & 4.27 & 1.00 & 54.2 & 51.8 & 0.96 & 409 & 424 & 1.04 & 12.1 & 11.8 & 0.98 \\
\hline & 大電洗 & 20.9 & 10 & 45 & 6.69 & 6.48 & 0.97 & 62.0 & 58.0 & 0.94 & 476 & 455 & 0.96 & 7.50 & 7.10 & 095 \\
\hline \multirow{2}{*}{$F$} & 小電流 & 31.3 & 3 & 0 & 3. 14 & 3.15 & 1.00 & 85.4 & 87.8 & 1.03 & 473 & 471 & 1.00 & 10.5 & 10.5 & 1.00 \\
\hline & 大電流 & 31.3 & 10 & 59 & 4. 24 & 4. 40 & 1.04 & 91.2 & 90.4 & 0.99 & 318 & 333 & 1.05 & 6. 38 & 6.15 & 0.96 \\
\hline \multirow{2}{*}{$G$} & 小電流 & 20,9 & 3 & 6 & 4. 62 & 4. 64 & 1.00 & 55.8 & 53.9 & 0.97 & 471 & 494 & 1.05 & 11.5 & 11.1 & 0.97 \\
\hline & 大電流 & 20.9 & 10 & 49 & 6.82 & 6.98 & 1.02 & 58.6 & 60.8 & 1.04 & 507 & 507 & 1.00 & 7.6 & 7.2 & 0.95 \\
\hline$B$ & |半䨔E & 10.5 & 16 & I1 & 2. $09^{\circ}$ & 2. 07 & 0.99 & 45.4 & 52.6 & 1.16 & 9.4 & 7.7 & 0.82 & 0.56 & 0.52 & 0.93 \\
\hline$F$ & $\mid \begin{array}{ll}2 & \text { 本 } \\
\text { 直 } & \text { 列 }\end{array}$ & 24 & 3 & 4 & 4. 55 & 4.55 & 1.00 & 109.4 & 99.9 & 0.91 & 441 & 449 & 1.02 & 9.5 & 8.8 & 0.93 \\
\hline
\end{tabular}

る平たん部では溶断後の電流時間皘分により，平たん 部の最小単位が溶罍・発弧するが，乙の值は通暼開始 からのジュール積分により変化する。こてでは, 計算 すを簡略化するため溶断後の電流時間皘分のみを考虑 し, 最小単位 1 個分溶瀜する電流時間積分值を平たん 部溶融係数 $A_{s m}(\mathrm{~A} \cdot \mathrm{s} /$ 個) とした。

\section{3. シミュレーション結果}

シミニレーションに使用した動作特性定数を表 2 に, 計算結果と実験結果の比較を表 3 亿示す。

$\langle 3.1\rangle$ 最大值の比較限流值, 動作過電圧, 了 一クエネルギーおよび動作時間の各シミュレーション 


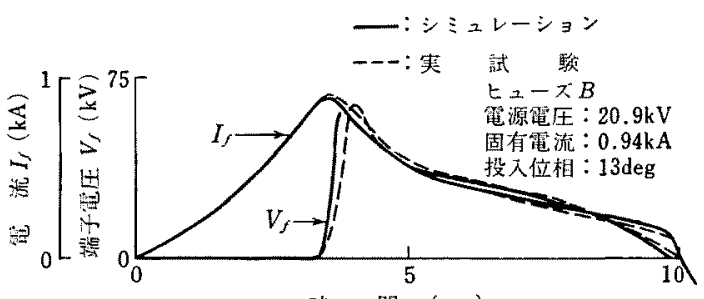

時 間 $t(\mathrm{~ms})$

図 4 最大アークエネルギー領域に括ける実測波形とシミュレ

$$
\text { ーション波形（ヒューズB） }
$$

Fig. 4. Comparison of wave-forms of simulation and test result inside the zone of maximum arc enargy (type $B$ fuse).

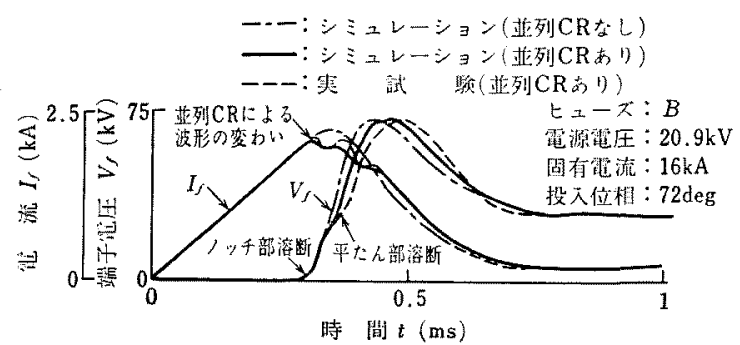

図 5 並列 $\mathrm{CR}$ を含む実测波形とシミュレーション波形

Fig. 5. Comparison of simulated results with/without a parallel $C R$ circuit and an actual test result.

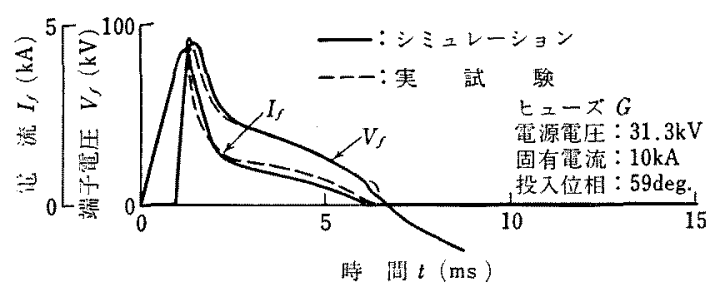

図 $636 \mathrm{kV}$ ヒューズの実測波形とシミュレーション波形（ヒューズG）

Fig. 6. Comparison of wave-forms of simulation and test result for a $36 \mathrm{kV}$ fuse link (type $G$ fuse).

値は, ヒューズ $A$ の大電流, ヒューズ $B$ の半電纴お よびヒニーズ $F$ の 2 本直列動作時 (〈3・3〉節参照)を 除けば，実験と比べて+5〜ー6\%の範用にあり，実 用上十分な精度で㢃く合っている。ヒューズ $A$ の大 電流，ヒューズ B D半電圧およびヒューズ Fの2本 直列動作時については別項で检討する。

〈3-2〉波形の比較 図4にヒューズBの固有電 流が $0.94 \mathrm{kA}$ (小電流域 : 最大アークエネルギー領域) における全体波形を示す。図 5 に同種ヒューズの固有 電流が $16 \mathrm{kA}$ (大電流域)における通笔開始から $1 \mathrm{~ms}$ までの波形定示す。更に，図 6 亿定格電圧が $36 \mathrm{kV}$ の ヒューズ $G$ の波形を示す。
いずれの波形においてすシミュレーション結果と実 測值亡は良く合っている。因5に放いて，ノッチ付工 レメントヒューズのノッチ部と平たん部が 2 段階に発 弧し，電匡の立上り部加 2 段階になっている状況む， 良くシミュレートされていることがわかる。

〈3.3〉電源電在 $1 / 2$ の場合とヒューズ 2 本直列動 作の場合 图 7 に電源電圧が $1 / 2$ の場合 (半電圧) の動作波形を示す。

半電压の実験における電流波形には，電源電圧を規 格值とした実験時に見られる尾を引くような部分がな く, 動作時間も $0.56 \mathrm{~ms}$ と短い。シミュレーションの 結果す同様となり，電源電王を $1 / 2$ とした場合でむ本 


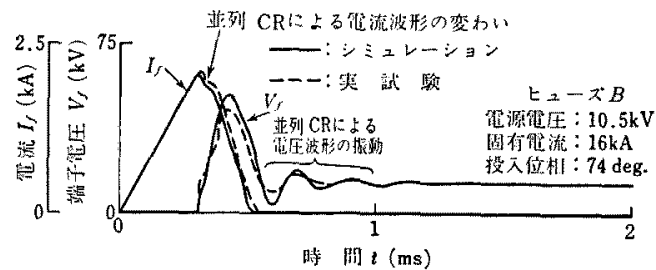

図 7 電源電压を $1 / 2$ とした場合の実測波形 とシミュレーション波形（ヒニーズB）

Fig. 7. Comparison of wave-forms of simulation and test result under the half source voltage (type $B$ fuse).

シミュレーションき法を適用できるととがわかった。 また，ヒューズ2本を直列にした場合で古シミュレー ション結果は半電王の場合と同じく聿測值とほぼ一致 した。

以上二つの特殊条件では，実测值に対するシミュレ ーション結果の相対䛊差は+16〜ー9\%の範囲にあ り，多少精度は低下したものの特性解析を行ううえで は十分使用できる䇙国にあると考えられる。

〈3.4〉再起電圧周波数謂整用抵抗およでキャパシ

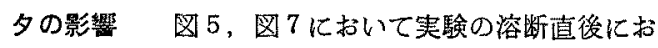
ける電流波形の变わいと図 7 におり西遮断直後の電圧 振動波は，ヒューズと並列に接続した再起電在調整用 抵抗 $R_{p}$ およびキャパシタ $C_{p}$ (图 1 参照) の影響で あり，とれは次のように考えられる。豁断直後の電死 急増により, キャパシタ $C_{p}$ に充電電流が流入するた め, ヒューズ笔流 $I_{f}$ は隇少する。また, 遮瞕時の七 ユーズ端子間電圧と電源電圧瞬時隹との差電压に上 り，電源リアクトル $L_{s}$ とキャパシタ $C_{p}$ との間に振 動を生ずる。ヒューズ B の大電流および半電壬のシ ミュレーションではこの回路条件を考慮しており，シ ミュレーション波形にも実験之同様な電流波形の変わ いと電圧の振動波形が見られる。图 5 亿は，再起電圧 調整用抵抗 $R_{p}$ とキャパシタ $C_{p}$ のない場合のシミュ レーション波形む示した。

てのように，再起電生調整用抵抗 $R_{p}$ およびキャパ シタ $C_{p}$ を考慮するととにより，より詳細なシミュレ ーションの可能なととがわかった。

\section{〈3・5〉ヒューズA の大電流域結果について}

ヒューズ A の大電流域実験においては, 図 8 に示 すようにエレメントの溶断状沉が実跧とシミュレーシ ョンとで買なり，そのため特に時間的推移に関して結 果が異なったと考えられる。以下にその考察を行う。

ヒニーズ $A$ の大電流域実験が，他の実験と大幅に 条件が異なるのは次の点である。

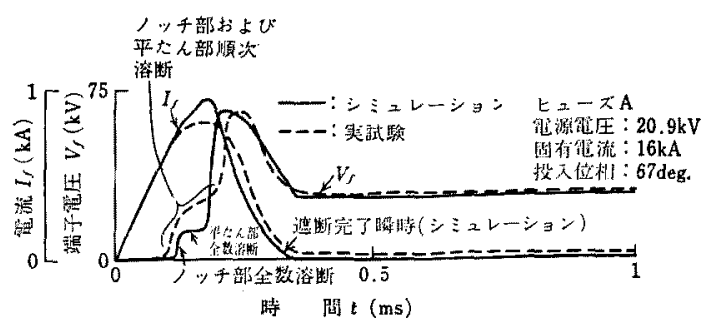

因 8 ノッチ部叔よび平たん部の溶断状況の

嗱い(ヒューズA)

Fig. 8. Defference of melting sequences of notch parts and llat parts (type $A$ fuse).

(1) ヒューズA はエレメント並列本数が1本て あるため, 各ノッチ部の溶断ジェール積分の最小㥀で 溶断時間が定まり，各ノッチ部の溶断ジニール積分の ばらつきが，そのまま溶断時間のばらつきとなる。他 方，エレメント並列本数加複数本のヒューズでは，1 本のエレメントの一部が溶断すれば他のエレメントに 流れる電流汃増加し，他のエレメントの溶断を早め る。このため，見措け上の溶断ジュール積分のばらつ き幅は小さくなる。

（2）固有電流と定格電流の比は，このヒニーズの 場合が今回の実験で一番大きく溶断時間は最小（約 $0.2 \mathrm{~ms}$ ) であり，エレメントの温度上昇は他のヒニー ズ出べて，より断熱状態と思われる。このため溶断 ジュール皘分のばらつきは，そのまま溶断時間のばら つきとなる。一方，溶断時間がてれより長い量合には， ノッチ部の局部的な湍度上昇はエレメント軸方向およ び砂への熱伝導により緩和され，見掛け上各ノッチ部 の溶断ジュール瞉分のばらつき6緩和されると思われ る。

以上の二点により，実験時には各ノッチ部および平 たん部は，かなりの時間的ばらつきをもって溶断した 亡考えられる。一方シシュレーションはばらつき幅 10\%で溶断するすのと設定したため，全ノッチ部およ び平たん部はほとんど同時に溶断し，動作過電圧の上 昇率は奏験より高く，またアークの党王成分 $V_{a r}$ が 高いため電流波形の尾を引くような部分がなく遮断を 完了したと考えられる。とのため，とのようなヒュー ズでは，溶断ジュール積分のばらつき幅を大きく設定 することと，ノッチ部の分割数を增加させることでシ ミュレーション精度を更に向上させるととができると 思われる。

$\langle 3 \cdot 6\rangle \quad$ シミニレーション定数の決定について

本論文のシミュレーションに使用した定数は, 実験 結果およびシミュレーション結果より，カット・アン 
ド・トライにより決定した。シミュレーション定数を 実験を行うことなく，ヒューズエレメント寸法より決 定できれば本手法の適用は搪大される。ヒューズエレ メント寸法よりシミュレーション定数決定する方法 については文献(6)を参照されたい。

\section{4. まとめ}

ノッチ付ヒューズエレメントをるつ限流ヒューズの 動作シミュレーション手法を開発した。本手法で考慮 した特徽は以下のと放りである。

（1）温度上昇の相違を考虑し，ノッチ部と平たん 部で異なる溶断シュール皘分を採用した。

（2）溶断ジュール積分を時間の関数上した。

(3) 多数䇫所のノッチ部と平た九部の溶断ジュー ル積分に，正晥分布に基づくげらつきをもたせた。

(4) /ッ千部が溶断すれば，その両側の平たん部 はアークによってる溶融・発弧する李のとした。

(5) 溶断後のアーク電王を電珐成分之抵抗成分 (抵抗降下電开) の直列回路で表した。

（6）電圧成分は一定值でなくアークエネルギーの 関数とした。

（7）抵抗成分はナーク周辽部を想定した溶断から の時間に上り直線的に增加する抵抗成分とアーク中心 部を想定したアークエネルギーの関数とした抵抗成分 の並列合成抵抗とした。

（8）アークの電死成分とアーク中心部の抵抗成分 に消弧砂に含まれる直堡の小さい仯を考慮した係数を 付加した。

（9）ヒューズと並列に接続される配電線路の対地
静電容量を考慮した。

以上のことを考虑した結果, $20 \mathrm{kV}$ 級限流七ューズ 7 種類，実験条件 16（短絡電流：0.6 16 kA，印加 電圧：全電圧々半電压，直列数：1本之 2 本など）の シミュレーション結果と実驗結果とは良い一致を示し た。本シミュレーション手法は，このように幅広い条 件に適用でき，動作過電圧だけでなく限流值，アーク エネルギーなどの検討にも使用できることがわかっ た。

最後に本研究を実施するにあたり，関西霞力(株)総 合技術研究所, 技術開発研究室 藤田武彦主任研究員 に治貴重心御指䆃，御援助を睗わった。きた，終始御 指導願った当所尾崎雾造所長, 山田重知副所長, 潹川 裕正部長ならびに実験に衔協力いただいた大電流研究 室各位にお礼申し上げます。

（昭和 61 年 6 月 17 日受付)

\section{文献}

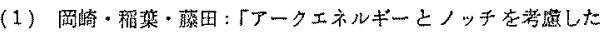

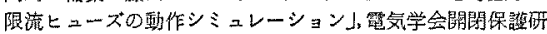
政, SPD $84-29$ (明 59-11)

（2）竹谷・黑由：「富士限流形筒形七ューズ」，富士赫報，40，525 (昭 42)

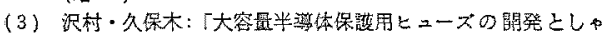
断オシロダラムのシミュレーション」, 昭 52 露気学会全大, No. 919 (昭 52)

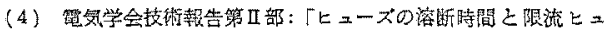
ーズの最大アークエネルギーについて」, p. 21 (昭 44-5)

（5）ヒューズハンドブック縞禁要貫会：ヒューズハンドブック p. 31 (昭 55-3) (株)ラテイス

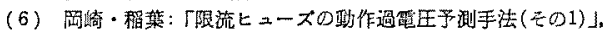
筆力中央研究所報告研究報告, 684012，21（昭 60-6) 